\title{
Students' Beliefs about their Interactions with Lecturers: Case of the National Institute of Youth, Physical Education and Sport (INJEPS)
}

\author{
Koffi Pierrot Edoh*, Alassane Biga Boukary \\ Laboratoire de Psychologie Sociale et Animations (LaPSA), Institut National de la Jeunesse, de l'Education Physique et du Sport \\ (INJEPS), Université d'Abomey Calavi (UAC), Porto-Novo, Benin \\ Email: *pedrokoff@yahoo.fr
}

How to cite this paper: Edoh, K. P., \& Boukary, A. B. (2019). Students' Beliefs about their Interactions with Lecturers: Case of the National Institute of Youth, Physical Education and Sport (INJEPS). Psychology, 10, 682-693.

https://doi.org/10.4236/psych.2019.105043

Received: March 11, 2019

Accepted: April 9, 2019

Published: April 12, 2019

Copyright () 2019 by author(s) and Scientific Research Publishing Inc. This work is licensed under the Creative Commons Attribution International License (CC BY 4.0).

http://creativecommons.org/licenses/by/4.0/

\begin{abstract}
At the National Institute of Youth, Physical Education and Sport (INJEPS), there is a belief circulating in some circles of students that lecturers develop subjective interactions with female students and those from their religions. The present study aims at evaluating the effect of the "gender" and "religion" on the academic achievements of INJEPS students in order to access these students' belief about the interactions their lecturers develop with them. To achieve that goal, the academic results of eight hundred and eighty-one (881) undergraduate and Master' students (671 males and 210 females), of various religions (698 Christian, 125 Muslims and 58 Animists) have been computed using the Generalised Linear Model (GLM) in R (3.0.2) Data Analysis Software. On the gender basis, the study revealed that, female students normally do better than male students $(p<0.05)$ on one hand. On the other hand, student's religion had no significant influences on their academic results whether they are male or female $(p>0.05)$. Conclusively, there is no tangible evidence to confirm the suspicions diffused among students since previous researches have shown that female students perform better than their counterpart male due to their assiduity and devotion to work.
\end{abstract}

\section{Keywords}

Academic Results, Beliefs, Gender and Religion, Interactions, Lecturers, Students

\section{Introduction}

This study was initiated from answers given by 100 level students during the first semester examination of social psychology courses of 2016-2017 academic year, 
in the Department of Science and Technique of Physical Activities and Sports (STAPS) of the National Institute of Youth, Physical Education and Sport (INJEPS) of the University of Abomey-Calavi (UAC). Actually, students were asked to show that "interactions that a lecturer develops with his learners can influence the results of these latter in one way or another". The lecturer, in view of the lessons taught, expected the students to reply that "affective interactions will positively impact the students' results while conflictual interactions will negatively impact them".

The students' answers went beyond what the lecturer expected from them. They also indicated that lecturers are influenced by non-formal factors in the relationships they initiate with their students and that it is these latter factors that ultimately determine the substance of their interactions with them and consequently their academic results. Thus, according to these students, lecturers are more interested to female students (endowed with attractive physical features) and students from their "religion" to whom they give the highest marks during tests and examinations. It is these unexpected answers that have led to more concern about the interaction between lecturer and students in this institute. Investigations on the matter have therefore continued during the academic year 2017-2018 to eventually extend to all the promotions of the last two years and the two departments of INJEPS.

Unconsciously or not, everyone is influenced by their social and/or cultural environment in the initiatives they take (CheAzmi \& Mustapha, 2014). These researchers have shown that between man and women, women generally perform better because they are more assiduous in their work. This difference among men and women at work is very limited among Chinese while it is quite pronounced among the Bumiputera in Malaysia where the tendency of a matriarchal community in the medium term is strongly considered. Moreover, Balkis \& Duru (2017) reported that in private schools, girls outperform boys.

Other studies have revealed that teachers are influenced in the exercise of their function and particularly in the interactions they develop with their students by factors such as information they have on learners (Edoh, Dosseville, \& Djaho, 2015). Information on the menu of meals served to learners is not to be neglected when it comes to the importance teachers give them. Accordingly, information about the quality of student's diet is another factor influencing the relationship between the teacher and his students (Cueto, 2001; Grantham-MacGregor, 2005; Ziani, Lim, Low, \& Harun, 2005). The involvement of students in sports is also reflected in the way teacher foresees their academic results and, consequently, his relationships with them (Edoh et al., 2015; Pfeifer \& Cornelissen, 2010; Rees \& Sabia, 2010). The teacher, depending on the way he perceives sport, may think that it will positively or on the contrary negatively impact the academic results of the students who practice it (Edoh et al., 2015). This appreciation will count in his interactions with his students and therefore affect their academic results. The socio-professional level of parents is also accountable in the interactions between the teacher and his learners (Epstein, 2001; Sheldon, 
2003). Interactions between teacher and student may also depend on how each of these actors perceives themselves and perceives others. Indeed, according to Durand and Riff (1991), student's beliefs regarding his teacher and reciprocally those of the teacher toward his student are susceptible to modulate their behaviours during physical education courses.

The majority of INJEPS teachers are male ( 33 men versus 3 women) as it is the case in most of the UAC entities (INJEPS included) and also in all other National Universities in Benin. What influences do variables (gender and religion) exert on them in the interactions they develop with their students during assessments? Except written and oral tests that are the personal initiative of each teacher, the correction of exam paper is done anonymously and under the supervision of the academic staff. Then how do teachers manage to recognize exam papers of students with attractive physical traits and those of their religion, in order to favour them? Do female students have better academic results than male students? What leads the students of INJEPS to believe that the interactions that their lecturers initiate with them during Classes are done on subjective bases? These are the questions to which this work aims to bring answers to.

\section{Forms of Beliefs}

There are two forms of beliefs: Traditional beliefs (primitive, endogenous or common sense) and beliefs of modern society (Moscovici, 2003). Whether traditional or modern, beliefs refer to two notions:

1) First, a notion that refers to "the action of believing" to something true, likely true, possible; that is to say "to affirm it with more or less certainty, confidence or conviction". This is about a subject that believes or doubts the contrary (Leguérinel, 1993; Edoh, 2004).

2) Secondly, a notion that refers to "what we believe", that is to say, "the content of the belief," its object. Thus, it designates the various processes whose purpose is to establish a degree of certainty, or of adhesion to a particular object in the universe of opinions.

Belief is an acquaintance or opinion that we trust or do not trust. It has a collective foundation and is valid for a community (De la Torre, 1991). In this case, we can say that INJEPS students believe that the interactions that their teachers develop with them depend on their gender or their religious denomination. This study draws its substance from common sense beliefs and is less focused on scientific knowledge.

\section{Beliefs of Common Sense}

Beliefs of common sense are knowledge that are as naive as true. They are shared by members of a community in a context of information deficit (Moscovici \& Hewstone, 1983). This means that people concerned are confronted with a situation to which they seek explanations. For this reason, they readily accept everything that justify what is happening to them or what concerns them because they 
do not have the right answer or reject it (the correct answer) because it does not solve their problem. It is a social thought, and as such, it implements two systems: one operating and one controlling (Drozda-Senkowska, Dubois, \& Mollaret, 2010).

\section{1) The Operating System}

It proceeds to the various mental operations, such as associations, inclusions, discriminations or deductions. In other words, it includes all the processes involved in the production of ideas (Drozda-Senkowaska et al., 2010). INJEPS students, at least those of them who think like this, who doubt their competence or have poor academic results are convinced that their colleagues who validated their Courses Units, have been favoured by their Lecturers (those of their religion, etc.). For that reason, they willingly accept everything that goes in the way that the interactions of the lecturer (INJEPS) with his students are conditioned by factors indicated above. It is a way of justifying their difficulties at the academic level.

\section{2) The Controlling System}

This second system checks and selects using different rules, what the first (operating system) produced. It reworks the (first) material produced by the operating system. It must be remembered that social thought or naive belief is marked by the primacy of the conclusion, that is to say that, the fact that the conclusion is already known and/or posited before the premises, thus allowing to display clearly the preferences or values of the group (Drozda-Senkowaska et al., 2010). It is known, it is like that and it is just to find everything that goes in the direction of the confirmation of the conclusion. INJEPS students are strict on the fact that the interactions their lecturers develop with them are based on gender or religion. What remains to them is to justify it. Arguments are therefore selected among those available, based on their justificatory value. It is put forward what makes it possible to affirm or strengthen the conclusion, its relevance. This type of thinking proceeds in the opposite way to scientific thought, where conclusions are drawn from premises by discovering the conclusion previously unknown. Everything happens as if the group members look for arguments to confirm the information circulating within them. Social thought is less oriented towards argument than justification. Indeed, by applying the principle of elective confirmation, it values any idea (information, memory, words) that goes in the direction of the expectations, or interests of the group. It uses examples as necessary and sufficient proofs (Rouquette, 1994).

A student of the same religion as the lecturer or assumed as such, had the highest grade or score for an examination or simply the student was seen with the Lecturer two days before the exam. This is sufficient to confirm the belief that INJEPS lecturer initiate subjective interactions with their students (assign the highest marks to girls with attractive physical traits or students of their religion). Previous results (grades, transcripts and marks during high School and various National examination, etc.) of the student indicated as having benefited from the lecturer's largesse are not taken into account. 
For all these reasons, social thought implies a strong repetition or redundancy or at least gives the impression of returning to the same leitmotiv, to translate it. Social thinking focused on communication (directional) is characterized by a decided judgment (Drozda-Senkowska et al., 2010). On the contrary modern belief draws its conclusions from the questions by discovering in the end, the conclusion that is unknown from the beginning.

\section{Forms of Interactions between a Lecturer and his Learners}

As for the forms of interaction between a lecturer and his learners, we will talk about self-fulfilling prophecies on the one hand and stereotypes and social comparison on the other hand.

\subsection{Self-Fulfilling Prophecies}

Teachers behave differently with their students in the interactions they initiate with them (contents of proposed assignment, positive or negative assessments, affection or indifference and feedback among others) (Sarrazin et al., 2005). What makes a teacher maintain differential relations with his own students? Depending on whether he or she has positive expectations from a student or group of students, his relations with them are in line with the said expectations. On the contrary, when he has negative expectations from others, consciously or otherwise, his interactions with them are in line with the confirmation of his expectations. These behaviours known (by Anglo-Saxon) as self-fulfilling prophecy (Merton, 1948), and in educational environment under the name of Pygmalion effect (Rosenthal \& Jacobson, 1968), means any perception or expectation of the teacher who changes the behaviour of students in conformity with the original expectation (Good \& Brophy, 2000).

Studies in sports context (Martinek, 1991; Trouilloud, 2002) as in educational context (Jussim, Smith, Madon, \& Palumbo, 1998; Trouilloud \& Sarrazin, 2003) confirm the tendency of teachers to influence the motivations and behaviours of students in the direction of their expectations. This research has shown that this process could be positive (high expectations of teacher generating better performance) or negative (low expectations of teacher leading to poor performance) (Sarrazin et al., 2005).

A study conducted in Quebec on immigrant minorities from Sub-Saharan Africa, where boys are more valued, has shown that they perform better than girls in their original cultural environments, whereas in Quebec, where boys and girls find themselves in the same social conditions, girls get the best school results (Mutombo \& WaBienge, 2004).

But Researchers remain cautious about the importance of this influence. They think the teacher's expectations are based on specific reasons, such as the information received on students from their average mark of previous classes for example. As a matter of fact, teachers rather predict student's behaviour than they actually modify them (Trouilloud \& Sarrazin, 2003). 
Researchers such as Sarrazin, Trouilloud, \& Bois (2005) have enumerated 4 successive steps to explain the interactions between teachers/lecturers and learners.

1) First, teachers on the basis of information they got on students at the beginning of the academic year, make projections after which they have expectations about each one. It is possible that in this case, a teacher is influenced by variables such as "physical traits of female students, religion or cultural realities, etc." of their students.

2) Secondly, this expectation in turn will exert an influence on their interactions (quality and quantity) with the students. In doing so, the interactions with the different students will be conditioned by their religion, their cultural environment and their gender among others.

3) In the third step of the sequence, teachers will have different treatments with students according to the group they belong to (student's religion or student's gender). These will be treated (well or otherwise) according to these criteria.

4) Fourth and finally, if this supposed or actual differential treatment between student groups persists, it will affect their motivation and influence their academic result in the direction of the teacher's expectations or wishes (Trouilloud, 2002). Female students identified as physically attractive and students of the lecturer's religion, maybe more motivated to work while those who perceive themselves to be unrelated to the lecturer will condition themselves psychologically to become self-handicapped.

Researches leading to the understanding of the effect of lecturer's beliefs and expectations in the sports context (Exercises or Sports Classes) has evaluated with the help of Smith, Smoll, \& Hunt (1977) models, the variables expectations and behaviours of lecturers or coach (Sarrazin et al., 2005). The results of these studies confirm the existence of differential treatment (quantity and quality of feedback) based on the lecturer's expectations (Trouilloud, 2002). These confirmations are only partial, because other studies have found no behavioural differences (Spallanzani, 1995) or indicated, on the contrary, that some lecturers devote more technical feedback and encouragement to low expectations (Martinek, 1988; Martinek \& Harper, 1984).

Definitely, lecturers rather enjoy teaching motivated students regardless their standards and their (lecturer's) expectations (Biddle \& Gouda, 1997). It is therefore not excluded, in one hand, that a lecturer pay more attention to students who are not from his religion or to female students with less attractive physical traits if they are diligent at work. On the other hand, it is also likely that the lecturer will be particularly demanding with students of his religion and female students in general to get them to give the best of their potential at work.

\subsection{Stereotypes and Social Comparison}

Besides the above reported works, other researches in social psychology have broached the issue of the self-fulfilling prophecy in relation to stereotypes (Co- 
dou \& Kerzil, 2007). Indeed, the lecturer can create groups within the class, whose behaviour he will predict. Students according to their group may be aware of the predictions made upon them by the lecturer. This can affect the perception of their competence and therefore of their performances, stereotypes being beliefs widely shared by everyone in a social environment (Croizet, Dessert, Dutrevis, \& Leyens, 2003).

A person who belongs to a stereotyped group can reach self-handicapping point leading to its failure in the educational domain (Codou \& Kerzil, 2007). Students who are not from the lecturer's religion and who are not a female with attractive physical assets, could already be limited in their interactions with the teacher and this will ultimately reflect on their motivation and therefore on their academic result.

According to the cited authors, in school context and especially in class, the relationships between lecturer and learner are asymmetric. Thus, the student is always expected to be evaluated by the lecturers and peers. Educational outcomes result from interactions between past and present situations of social comparison in which students are assessed in relation to their peers (Codou \& Kerzil, 2007). Students who are not from the lecturer's religion and students who are not "selected" by the lecturer will reach self-handicap and negatively foresee their result in contrast to others (those who have the lecturer's attention) who will be motivated and will do their best not to disappoint their lecturers. A better psychological and social condition could be an additional source of motivation (Mutombo \& WaBienge, 2004).

\section{Hypothesis}

Referring to Biddle and Gouda (1977) who showed that lecturers rather enjoy teaching to diligent students who are keen to acquire more knowledge regardless their background and level and to Mutombo \& WaBienge (2004) who have shown that placed in the same social conditions, the female often do better than male at school, we state that at INJEPS, lecturers develop objective interactions with their students regardless of their gender and religion.

\section{Objectives}

The objective of this study is to evaluate the effect of 'Sex' and 'Religion' on the academic achievements of INJEPS' students in order to access the beliefs of these students about the interactions their initiate with their lecturers.

\section{Methodology}

The academic results of eight hundred and eighty-one (881) INJEPS' students (STAPS and STASE Department), from the set of 2015-2016 and 2016-2017 academic years were taking into account for this study. These samples of students were constituted of all levels of undergraduate and Master's students whose academic results have been transmitted by the INJEPS academic staff to 
Education office of the University of Abomey-Calavi (UAC) and validated by this latter. They are distributed as indicated in Table 1.

\section{Statistical Analysis}

The academic results of the INJEPS' students taking into account were analysed using a Generalized Linear Model (GLM) in R Data Analysis Software, version 3.0.2. Thus, analyses were performed according to the model as follows:

$$
Y_{i j k}=\mu+S_{i}+H_{j}+(S H)_{i j}+\varepsilon_{i j k}
$$

where:

$Y_{i j k}$ : the observation for dependent variables;

$\mu$ : the general mean;

$S_{i}$ : the fixed effect of the sex ( $i=$ Male, Female);

$H_{j}$ the fixed effect of the religion ( $j=$ Christian, Muslim, Animist);

$(S H)_{i j}$ : the effect of the correlation between sex and religion;

$\varepsilon_{i j k}$ : the effect of the residual error.

Mean value of significant Factors and their standard deviations are computed using excel in office 2013. The significant effect of the sex, the religion and their correlations on the academic results were reported when $p$-value $<0.05$.

It is also important to notice that school marks in this study in this study is over 20 as in all educational institution in Benin generally.

\section{Results}

Results of the generalized linear model and the average mean and standard deviation of the factor "Sex" are shown in Table 2 and Table 3.

Table 1. Distribution of the 881 students based on religion and sex.

\begin{tabular}{cccccc}
\hline & & Religion & \multicolumn{3}{c}{ Sex } \\
\hline Variables & Christian & Muslim & Animist & Male & Female \\
\hline Number & 698 & 125 & 58 & 671 & 210 \\
\hline
\end{tabular}

Table 2. Result of the Linear model (ANOVA).

\begin{tabular}{cccc}
\hline Factor & Df & F value & Probability $(>\mathrm{F})$ \\
\hline Sex & 1 & 11.874 & $0.006^{* * *}$ \\
Religion & 2 & 0.569 & 0.566 \\
Sex: Religion & 2 & 0.356 & 0.701 \\
Residuals & 875 & & \\
\hline
\end{tabular}

Table 3. Average marks comparison between male and female students.

\begin{tabular}{ccc}
\hline Sex & Average marks (over 20) & Standard Deviation \\
\hline Male & 13.190 & 0.777 \\
Female & 13.397 & 0.703 \\
\hline
\end{tabular}




\section{Discussion}

The averages Marks of the male and female students are $13.190 \pm 0.777$ and $13.397 \pm 0.703$ respectively $(p<0.05)$. This result shows that the INJEPS female students for the academic years 2015-2016 and 2016-2017, statistically did better than male students. These outcomes are congruent with Mutombo and WaBienge (2004) works who found that, given the same social conditions as boys, girls obtain the best academic results. Actually, in the University of Abomey-Calavi and especially at INJEPS, male and female students generally live in the same social conditions as opposed to the socio-cultural realities in traditional communities in the republic of Benin where differential treatments remain and are to the advantages of males. While making statement on the result of the baccalaureate, session of July 2018, the minister in charge of the higher education in Benin, affirmed that the results of female candidates were better than those of male candidates. This statement of the minister is also in agreement with our results. Therefore, we cannot stick to the beliefs circulating in some student circles that INJEPS teachers develop subjective interactions with their learners (CheAzmi \& Mustapha, 2014).

There are some fields of studies especially literary fields (arts, arts and humanities and social sciences) where the results are generally to the advantage of female students. The study conducted in the departments of STAPS and STASE where learners are mainly subjected to literary disciplines (STASE) and to both literary and scientific disciplines, not to mention the practical trainings (STAPS) confirms this observation.

The STAPS department equally dominated by practical and physical subjects along with academic disciplines such as biological, human and social sciences and the STASE department which is essentially oriented towards the human and social sciences are more favorable to female students who are able to value themselves more than male students (Balkis \& Duru, 2017). However, it should be noted that in the case of physical and practical tests, grading and evaluation scales vary according to sex. The present results, beyond the suspicions diffused in certain groups of students, can be explained by a better assiduity within the female students who are more devoted to work than the male students (Balkis \& Duru, 2017).

Nevertheless, other studies have shown that in disciplines such as science and especially mathematics, and in some communities (China), the results are similar between male and female or that it is in some cases the male students who obtain the best results (CheAzmi \& Mustapha, 2014).

Unlike the factor "sex" $(p<0.05)$, "religion" and the interaction between sex and religion have no significant effect $(p>0.05)$ on the academic results of INJEPS students. Actually, in Benin, religion does not constitute a barrier among the different communities. For example during religious festivities leaders and disciples of the cults concerned are sometimes supported by the disciples of other religions. Besides inter-religious marriage is frequent in Benin. As matter of 
fact, in the same family, believers of all faiths can live and work together (Edoh, 2004, Glèlè, 1981). Hence, the notion of religion and the faith of each individual are not always easy to appreciate and family names and given names are not reliable indicators. Moreover faith-based schools, whether primary, secondary or tertiary, welcome all learners without distinction of religion. We therefore understand why the factor religion has no influence on the academic results of the students. Accordingly, it is not possible to state that one religion or another has any significant effect on academic results of the students.

\section{Conclusion}

This work brings some additional information on the influence of sex and the religion effect on academic results. It even goes further by embracing the consequences (negative or positive) that the social and cultural environment can exert on subgroups of a community as it values or devalues them. It also helped us to better situate ourselves regarding the belief that circulates inside the INJEPS about the interactions that lecturers of this institute initiate with their students. But are these results enough for students who attribute their failures to subjective reasons to pull themselves together and change their beliefs?

What is important to notice is that this research offers new perspectives, as it gives the opportunity to carry out a comparative study between the two departments (STAPS and STASE) of the institute. This comparative study in these departments will help to better assess the effect of the variable "sex" on the academic results in each of these department. If the result is conclusive, it will eventually help to improve the guideline policy of students at the beginning of each academic year in order limit cases of failures among students. In fact, students are more and more attracted to studies in this institute. Consequently, the number of students enrolment increases from year to year. Success in the STASE, which is essentially focused on literary disciplines, human and social sciences on one hand, and the STAPS whose training offers embrace both literary, biological and physical disciples, on the other hand, can be differently influenced by gender, because men and women may not have the same skills in academic disciplines.

\section{Conflicts of Interest}

The authors declare no conflicts of interest regarding the publication of this paper.

\section{References}

Balkis, M., \& Duru, E. (2017). Gender Difference in the Relationship between Academic Procrastination, Satisfaction with Academic Life and Academic Performance. Electronic Journal of Research in Educational Psychology, 15, 105-125.

https://doi.org/10.14204/ejrep.41.16042

Biddle, S. J., \& Gouda, M. (1977). Effort Is Virtuous: Teacher Preferences of Pupil Effort, Ability and Grading in Physical Education. Educational Research, 39, 3500-3550. 
CheAzmi, A., \& Mustapha, M. Z. (2014). The Role of Competitiveness, Gender and Ethnicity in Influencing Academic Performance. Malaysian Online Journal of Educational Management, 2, 37-47.

Croizet, J.-C., Désert, M., Dutrévis, M., \& Leyens, J.-P. (2003). L’impact des réputations d'infériorité sur les performances intellectuelles. Revue Internationale de Psychologie Sociale, 16, 97-124.

Codou, O., \& Kerzil, J. (2007). L'école à la lumière de la psychologie sociale. Deuxième partie: Stéréotypes et relations au savoir. Carrefour de l'éducation, 1, 153-169. https://doi.org/10.3917/cdle.023.0153

Cueto, S. (2001). Breakfast and Performance. Public Health Nutrition, 4, 1429-1431. https://doi.org/10.1079/PHN2001233

De la Torre, I. (1991). Le vodu en Afrique de l'ouest, rites et traditions. Paris: Editions Harmattans.

Drozda-Senkowaska, E., Dubois, N., \& Mollaret, P. (2010). Psychologie Sociale. Paris: Presse Universitaire de France.

Durand, M., \& Riff, J. (1991). Relation pédagogique et apprentissage en éducation physique: Effet des croyances des maîtres et des élèves. In J.-P. Famose, P. Feurance, \& Y. Touchard (Eds.), L’apprentissage moteur. Rôle des représentations (pp. 175-199). Paris: Editions Revue EPS.

Edoh, K. P. (2004). Les croyances traditionnelles et les motivations chez les élèves en République du Bénin. Thèse de doctorat de l'Université de Caen.

Edoh, K. P., Dosseville, F., \& Djaho, R. (2015). Pratique sportive, attente de l'enseignant et résultats scolaires: Le cas du lycée des jeunes filles de Lokossa au Bénin. Revue de Langues, Lettres, Arts, Sciences Humaines et Sociales, 2, 111-129.

Epstein, J. L. (2001). School, Family, and Community Partnerships: Preparing Educators and Improving Schools. Boulder: Wesview Press.

Grantham-MacGregor, S. (2005). Can the Provision of Breakfast Benefit School Performance? Food Nutrition Bulletin, 26, 144-158. https://doi.org/10.1177/15648265050262S204

Glèlè, A. M. (1981). Religions, culture et pratique d'Afrique noire (p. 206). Paris: Economica, Présence Africaine.

Good, T. L., \& Brophy, J. E. (2000). Looking in Classrooms (8th éd.). New York: Longman.

Jussim, L., Smith, A., Madon, S., \& Palumbo, P. (1998). Teacher Expectations. Advances in Research on Teaching, 7, 1-48.

Leguérinel, N. (1993). Pertinence du concept d'acculturation pour l'individu (pp. 47-53). Bastidiana, No. 4, Cahiers d'étudesbastidiennes.

Martinek, T. (1988). Confirmation of a Teacher Expectancy Model: Student Perceptions and Causal Attributions of Teaching Behaviors. Research Quarterly of Exercice and Sport, 59, 118-126. https://doi.org/10.1080/02701367.1988.10605488

Martinek, T. (1991). The Psycho-Social Dynamics of Teaching Physical Education. Dubuque, IA: Brown/Benchmark.

Martinek, T., \& Harper, W. (1984). The Effects of Noncompetitive and Competitive Social Climates on Teacher Expectancy Effect in Elementary Physical Education Classes. Journal of Sport Psychology, 8, 408-421. https://doi.org/10.1123/jsp.6.4.408

Merton, R. K. (1948). The Self-Fulfilling Prophecy. Antioch Review, 8, 193-210. https://doi.org/10.2307/4609267 
Moscovici, S. (2003). Le domaine de la psychologie sociale (pp. 6-22). Paris: Presse Universitaire de France.

Moscovici, S., \& Hewstone, M. (1983). Social Representations and Social Explanations: From the "Naïve" to the "Amateur" Scientist. In M. Hewstone (Ed.), Attribution Theory: Social and Functional Extentions (pp. 98-125). Oxford: Basil Blackwel.

Mutombo, J.-P. M., \& Wa Bienge, G. N. (2004). Etude sur la disparité des performances scolaires entre les sexes. Journal of International and Integration, 5, 449-479. https://doi.org/10.1007/s12134-004-1023-9

Pfeifer, C., \& Cornelissen, T. (2010). The Impact to Participation in Sports on Educational Attainment-New Evidence from Germany. Economics of Education Review, 29, 94-10. https://doi.org/10.1016/j.econedurev.2009.04.002

Rees, D., \& Sabia, J. J. (2010). Sports Participation and Academic Performance: Evidence from the National Longitudinal Study of Adolescent Health. Economics of Education Review, 29, 751-759. https://doi.org/10.1016/j.econedurev.2010.04.008

Rosenthal, R., \& Jacobson, L. (1968). Pygmalion in the Classroom: Teacher Expectation and Pupils' Intellectual Development. New York: Holt, Rinehart and Winston.

Rouquette, M. (1994). Sur la connaissance des masses. Grenoble: Presse Universitaire de Grenoble.

Sarrazin, P., Trouilloud, D., \& Bois, J. (2005). Les attentes du superviseur et performance sportive du pratiquant. Amplitude et fonctionnement de l'effet pygmalion en contexte sportif. Bulletin de Psychologie, 58, 63-68. https://doi.org/10.3917/bupsy.475.0063

Sheldon, S. (2003). Linking School-Family-Community Partnership in Urban Elementary Schools to Student Achievement of State Test. Urban Review, 35, 149-165. https://doi.org/10.1023/A:1023713829693

Smith, E., Smoll, F., \& Hunt, E. (1977). A System for the Behavioral Assessment of Athletic Coaches. Research Quaterly, 48, 401-408.

Spallanzani, C. (1995). Description de l'effet pygmalion sur le temps d'apprentissage offert à des élèves en éducation physique au primaire. Avante, 1, 1-18.

Trouilloud, D. (2002). L'effet pygmalion en EPS: Réalité, processus médiateur et variables médiatrices de l'influence des attentes de l'enseignant sur la motivation et la performance des élèves. Thèse de doctorat, Grenoble: Université Joseph Fourier.

Trouilloud, D., \& Sarrazin, P. (2003). Les connaissances actuelles sur l'effet pygmalion: Processus, poids et modulateurs. Revue Française de Pédagogie, 145, 89-119. https://doi.org/10.3406/rfp.2003.2988

Ziani, M. Z., Lim, C. T., Low, W. Y., \& Harun, F. (2005). Effects of Nutritional Status on Academic Performance of Malaysian Primary School Children. Asia Pacific Journal of Public Health, 17, 81-87. https://doi.org/10.1177/101053950501700204 